\title{
Socio-Economic Factors and Rural Competitive Advantage: The Moderating Role of Economic Literacy*
}

\author{
Hendra RUSTANTONO ${ }^{1}$, Budi Eko SOETJIPTO ${ }^{2}$, Wahjoedi WAHJOEDI ${ }^{3}$, Sunaryanto SUNARYANTO ${ }^{4}$
}

Received: June 06, 2020 Revised: June 28, 2020 Accepted: July 12, 2020

\begin{abstract}
This study aims to determine the factors influencing the community behavior in improving competitive rural tourism as well as understanding the role of economic literacy in mediating socio-economic indicators and rural competitive advantage. This research followed an explanatory research to examine the relationship between variables including socio-economic variables and rural tourism competitive advantage. The data was gathered by conducting observations and interviews with tourism businesses, stakeholders, and the local village government, and related agencies as respondents. Furthermore, the data were analyzed following inductive and descriptive statistics. The findings indicated that, from all variables used, solely the environmental impact variable did not affect economic literacy and the competitive advantage of rural tourism. The moderating variables showed that the economic literacy mediates the economic impact on rural tourism competitive advantage. In addition, socio-cultural impacts on rural competitive advantage tourism, and the stakeholder involvement affects rural competitive advantage tourism. However, economic literacy failed in mediating between environmental impacts on rural competitive advantage tourism. This is due to the increasing understanding of the economy of the community around the tourist attractions it will increase the business around the tourist attractions that have an impact on environmental damage around the tourist attractions.
\end{abstract}

Keywords: Rural Competitive Advantage Tourism, Economic Literacy, Socio-Economic Impact, Structural Equation Model

JEL Classification Code: P25, R11, Z30

\section{Introduction}

The rural tourism plays an important role to increase economic growth, eradicate poverty, overcome

\footnotetext{
${ }^{*}$ Acknowledgements:

We are grateful to anonymous reviewers and editor of the journal for their valuable comments and suggestions an effort to improve the quality of article.

${ }^{1}$ First Author and Corresponding Author. Doctoral Program in Economic Education, Faculty of Economics, Universitas Negeri Malang, Indonesia [Postal Address: Jalan Semarang 5, Malang 65415, Indonesia] Email: hendrarus09@yahoo.com

${ }^{2}$ Faculty of Economics, Universitas Negeri Malang, Indonesia. Email: budi.eko.fe@um.ac.id

${ }^{3}$ Faculty of Economics, Universitas Negeri Malang, Indonesia. Email: wahjoedi.fe@um.ac.id

${ }^{4}$ Faculty of Economics, Universitas Negeri Malang, Indonesia. Email: sunaryanto.fe@um.ac.id

(c) Copyright: The Author(s)

This is an Open Access article distributed under the terms of the Creative Commons Attribution Non-Commercial License (http://Creativecommons.org/licenses/by-nc/4.0/) which permits unrestricted noncommercial use, distribution, and reproduction in any medium, provided the original work is properly cited.
}

unemployment, improve individual welfare, preserve nature, the environment, and resources, promote culture, elevate the nation's image, and strengthen national identity (Muhanna, 2007; Purnomo et al., 2020). Rural tourism touches various aspects of society, including ideological, political, economic, and socio-cultural manner (Tosun, 2000; Truong et al., 2020). Therefore, it is the expected of various stakeholders that tourism sector can achieve community welfare goals even though it has not yet provided maximum economic value to the community (Suranto et al., 2020).

The current literature on tourism development has noted that communities are central to the development of sustainable tourism (Chamidah et al., 2020). However, it pays little attention to analyzing community concepts or how communities influence outcomes. For example, Scherl and Edwards (2007) described local communities as groups of people with similar identities who may be involved in various aspects of related livelihoods. It is also noted that local communities often have customary rights relating to the region and its natural resources and strong links with the area culturally, socially, economically, and spiritually. 
Furthermore, Figgis and Bushell (2007) stated that the development and conservation of tourism that denies the rights and concerns of local communities is self-defeating, if not illegal. Therefore, the involvement of local communities in the development of tourism cannot be ignored because they play such an important role. Jamal and Stronza (2009) added that involving local communities in the development of tourism in and around protected areas is very important in bridging the gap between governance and the use of resources in tourism destinations. The involvement in tourism development can also be beneficial in many purposes such as create effective environmental management built on original, local and scientific knowledge, economic development, social empowerment, protection cultural heritage and the creation of interpretive and natural-based experiences for learning tourism and cross-cultural appreciation (Jamal \& Stronza 2009; Warouw et al., 2019).

Lo et al. (2015) suggested that rural tourism is rapidly growing with the potential to contribute to economic growth. In order for rural tourism to succeed, it must be competitive within the overall tourism sector. The integrated competitiveness model of Dwyer and Kim (2003) uses seven components to assess tourism destination competitiveness, namely, core or natural resources; cultural heritage resources; artificial resources; supporting resources; goal management; situational conditions; and demand conditions. According to Jappelli (2009), in principle, economic literacy is a means to an end, but in reality, not everyone has high economic literacy and reduces opportunities for welfare. One indicator is to be smart people in managing their economic resources to prosper. McKercher (2003) added that sustainable tourism leads to the management of all resources in such a way that economic, social and aesthetic needs can be met while maintaining cultural integrity, important ecological processes, biodiversity, and life support systems.

The district of Malang has a great potential in tourism sectors combined with the local wisdoms. Along the Southern Cross Lane Malang, it is linked with the tourism sites in Malang such as Balekambang beach, Sendang Biru beach, and several other beaches. Southern Cross Lane in Malang is an area that is very much related to the livelihood of many people in the area (Wulandari et al., 2019). It is supported by the beauty and uniqueness of attractions, accessibility, readiness of the socio-economic environment and services of local communities, climate conditions, the existence of accommodation, supporting facilities and infrastructure, availability of clean water, and guaranteed security.

However, the high competition of tourist attractions in Malang requires a good management strategy and environmentally-sound management. The development program needs the following attention such as monitoring the preservation of natural resources, increasing comfort for tourists, improving the quality of local human resources, capital policies for residents in developing businesses that support tourism, knowledge of the community, counseling and guidance for local communities to be directly involved in tourism services, and maintenance of resources nature and environment. For these matters, this study is intended to explore ideas and views formed previously by local communities about their role in tourism development in the context of the local community domain. This study aims to determine the factors that influence people's behavior including economic, environmental, sociocultural, and stakeholder involvement in order to increase the attractiveness of rural tourism, which is moderated by economic literacy in Malang of East Java.

\section{Literature Review}

Rural tourism is a rapidly expanding tourism segment with the potential to contribute to economic growth (Lo et al., 2015). However, the development of rural tourism destinations must be carried out in a way that maximizes the objectives of competitive advantage (Neto, 2003; Sharpley, 2002). The findings showed that stakeholder involvement in tourism, community knowledge about tourism and the environmental impact of tourism has a significant positive impact on rural competitive advantage, while the economic and socio-cultural impacts of tourism, as well as community support for tourism have little influence (Lo et al., 2015; Stylidis et al., 2014).

To increase tourism, there is a need for community involvement, in terms of actors, roles and interests (Ismayanti, 2010). The participation of the community in supporting tourism programs has an important meaning for increasing income and the experience of visiting tourists (Jamal \& Getz, 1995; Getz \& Page, 2016). The indigenous people of the local area need to get an understanding of the marine tourism business and how to protect coral reefs in an effort to be a good host.

Previous study by Nakatani and Teixeria (2009) showed that the cities they studied did not use or did not know how to use available resources in creating value. The cities studied did not fully exploit their tourism resources and organizational resources that were available. Jappelli (2009) mentioned that, in principle, economic literacy is a tool to achieve goals, but in fact, not all people have high economic literacy and this reduces opportunities for prosperity. One marker of economic literacy is managing one's economic resources effectively in order to prosper (Mazilu \& Popescu, 2010).

\section{Research Methodology}

This research followed an explanatory research to examine the relationship between variables including 
economic variables and rural tourism competitive advantage. This study was conducted in all tourism of the district of Malang of East Java Indonesia. The data was gathered by conducting observations and interviews with tourism businesses, stakeholders, and the local village government, and related agencies as respondents. The items of questionnaires are related to the development of rural tourism competitive advantages and research was carried out for six months. The number of respondents in this study totaled 172 respondents. The data analysis method used provided sample data with inductive statistics and descriptive statistics that are regenerated for population conclusions. In more detail, the conceptual framework of this research is illustrated in Figure 1.

\section{Results and Discussion}

\subsection{The Demographics of Respondents}

Table 1 provides information about the characteristics of the respondent. In general, the highest number of respondents is working in society, while the lowest one is working in village government. In more detail, approximately
6.4 percent of respondent working as a travel agent, 6.9 percent and 7.6 percent are working as tourism agent and tourism officer, respectively. However, some people also work in the NGOs and hotel and restaurant sector. Besides, the grouping of respondents by age is dominated by the 25-to-30 age bracket, with 27.9 percent. The second and third highest percentage were people in the age 30-to-35 and 35-to-40 years old, respectively. The lowest percentage were respondents in the 45-to-50 age bracket. From the educational background, half the respondents graduated only from senior high school. Approximately 43 percent had a bachelor degree and only about 12 percent graduated with master and doctoral degrees.

Figure 2 illustrates the theoretical model development diagram. From the figure, it can be seen that the path coefficient value of the economic impact on economic literacy is 0.402 , while the economic impact on rural competitive advantage tourism is -0.045 . In addition, environmental impact on economic literacy is -0.574 and environmental impact on rural competitive advantage tourism is 0.133 . Further, from the figure, we note the socio-cultural impacts on economic literacy by 0.233 , then socio-cultural impacts on rural competitive advantage tourism by 0.787 . The relationship

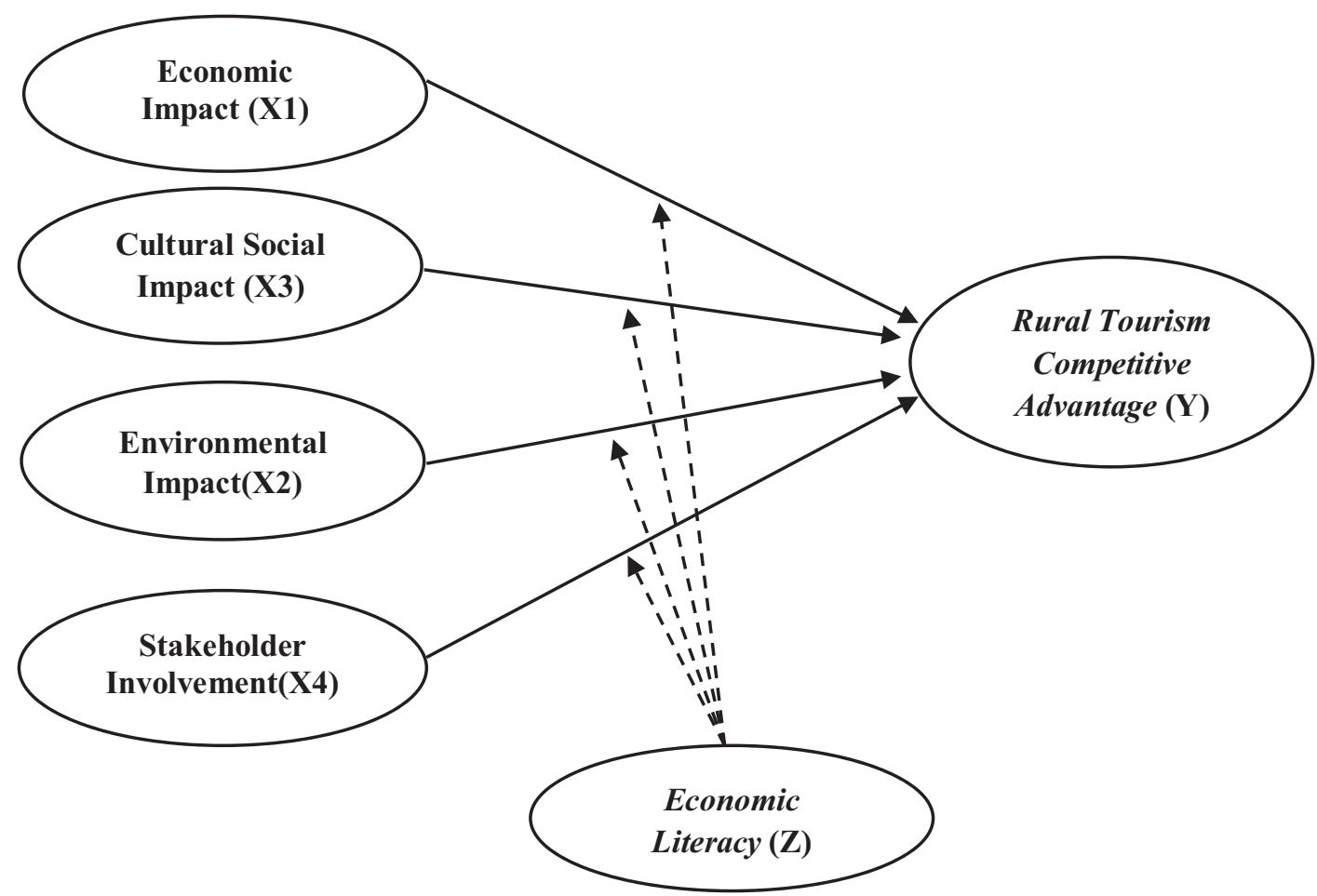

Figure 1: Research Framework

Description: $\mathrm{X} 1, \mathrm{X} 2, \mathrm{X} 3$ and $\mathrm{X} 4$ = independent variables, $\mathrm{Y}=$ dependent variable, $\mathrm{Z}=$ moderating variable 
Table 1: Characteristics of Respondents

\begin{tabular}{|c|c|c|}
\hline Respondents & Total & Percentage (\%) \\
\hline \multicolumn{3}{|l|}{ Respondents by gender } \\
\hline Men & 80 & $46.5 \%$ \\
\hline Women & 92 & $53.5 \%$ \\
\hline \multicolumn{3}{|l|}{ Respondents by job type } \\
\hline Village government & 10 & $5.8 \%$ \\
\hline Travel agents & 11 & $6.4 \%$ \\
\hline Hotels and restaurants & 24 & $13.9 \%$ \\
\hline Travel & 12 & $6.9 \%$ \\
\hline Society & 76 & $44.2 \%$ \\
\hline Tourism Office & 13 & $7.6 \%$ \\
\hline Environmental NGOs & 26 & $15.1 \%$ \\
\hline \multicolumn{3}{|l|}{ Respondents by age } \\
\hline $25-30$ years & 48 & $27.9 \%$ \\
\hline 30-35 years & 33 & $19.2 \%$ \\
\hline $35-40$ years & 34 & $19.7 \%$ \\
\hline 40-45 years & 27 & $15.7 \%$ \\
\hline $45-50$ years & 14 & $8.1 \%$ \\
\hline$>50$ years & 16 & $9.3 \%$ \\
\hline \multicolumn{3}{|c|}{ Respondents based on the education level } \\
\hline High school & 86 & $50 \%$ \\
\hline High (Bachelor Degree) & 74 & $43 \%$ \\
\hline Master and Doctoral & 12 & $6.9 \%$ \\
\hline
\end{tabular}

between economic literacy and rural competitive advantage tourism is shown by 1.017, and stakeholder involvement with economic literacy by 0.021 . Lastly, the impact of economic literacy on rural competitive advantage tourism and the impact of stakeholder involvement on rural tourism competitive advantage is reflected by -0.025 .

\subsection{Validity and Reliability Test}

This study conducted validity tests to separate the invalid statement item from valid statement items. It is found that all the question items are statistically valid (with $\mathrm{df}=172-6=$ 166 and 5 percent significance of 0.1273 ). The researchers also tested the reliability level by looking at Cronbach's Alpha value toward our model, with the reliable variables having a Cronbach's Alpha value $>0.6$. The results showed that all variables (including latent variables) $>0.6$, as seen in Table 2, meaning all variables were reliable.

Since the validity is adequate, the model reached convergence condition and the outer output loadings all indicators meet the convergence validity assumption. This shows that all the indicators in latent variables are divergent to explain the quality of the constructs. The discriminant validity of the indicator can be seen in cross-loading between the indicator and its latent variables.

\subsection{Hypothesis Testing}

Before the hypothesis testing, the researchers performed a bootstrapping procedure on the sample data. The result of bootstrapping with bootstrap sample assumed that the data has normal distribution, so that the parameter test in the model can be done by a t-test. The coefficient value of the structural model is said to be significant if the t-count $>\mathrm{t}$-table is 1.96 ( 1.96 is the t-table value in the $95 \%$ confidence level). All significant indicators in the hypothesis test results for the outer model are used to build the model, while the results of the inner model hypothesis test can be seen in Table 3 with the results of all significant path coefficients.

As shown in Table 3, the economic impact variable had a significant influence on economic literacy with a p-value of 0.030 . This is consistent with the hypothesis that the economic impact has a significant effect on economic literacy. Economic impacts are explained as net economic changes in the host community resulting from expenditures associated with an event or facility (Turco \& Kelsey, 1992). Job creation, entrepreneurial opportunities, enormous investment attractiveness, and contributions are examples of economic impacts that lead to an increase in economic position and a better life at the destination.

The economic impact variable had a significant effect on rural competitive advantage tourism with a p-value of 0.027 . This is consistent with the proposed hypothesis that economic impact has a significant effect on tourism's competitive advantage in rural areas. According to Walpole and Godwin (2000), tourism is a tool for economic development. Local people support the development of tourism because tourism activities will lead to economic development, such as providing investment opportunities and as a new source of income generation (Yon et al., 2004). Previous research

Table 2: Evaluation of Measurement Model

\begin{tabular}{|l|c|c|}
\hline \multicolumn{1}{|c|}{ Variables } & $\begin{array}{c}\text { Cronbach's } \\
\text { Alpha }\end{array}$ & $\begin{array}{c}\text { Composite } \\
\text { Reliability }\end{array}$ \\
\hline Economic Impact & 0.898 & 0.900 \\
\hline Environmental Impact & 0.899 & 0.898 \\
\hline Cultural Social Impact & 0.879 & 0.880 \\
\hline Economic Literacy & 0.844 & 0.838 \\
\hline Stakeholder involvement & 0.851 & 0.851 \\
\hline $\begin{array}{l}\text { Rural tourism competitive } \\
\text { advantage }\end{array}$ & 0.834 & 0.838 \\
\hline
\end{tabular}




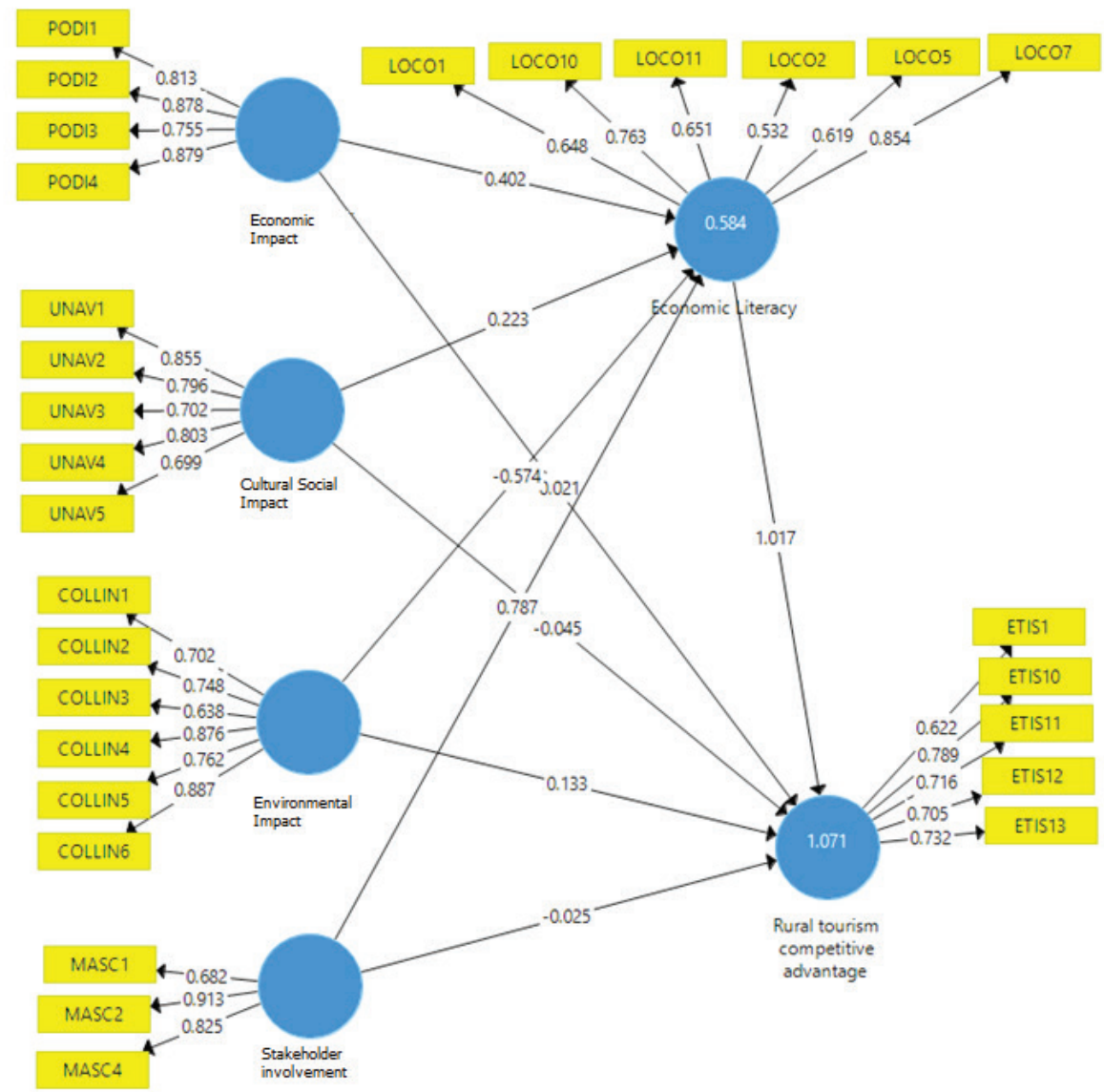

Figure 2: Theoretical Model Development Diagram

Table 3: Values of t-test for Path Coefficients

\begin{tabular}{|l|l|c|c|c|c|c|}
\hline & & $\begin{array}{c}\text { Original } \\
\text { Sample (O) }\end{array}$ & $\begin{array}{c}\text { Sample } \\
\text { Mean (M) }\end{array}$ & $\begin{array}{c}\text { Standard } \\
\text { Deviation } \\
\text { (STDEV) }\end{array}$ & $\begin{array}{c}\text { T Statistics } \\
\text { (|O/STDEV|) }\end{array}$ & P Values \\
\hline $\mathbf{H}_{1}$ & Economic Impact $\rightarrow$ Economic Literacy & 0.402 & 0.530 & 2.464 & 0.663 & 0.030 \\
\hline $\mathbf{H}_{2}$ & $\begin{array}{l}\text { Economic Impact } \rightarrow \text { Rural competitive } \\
\text { advantage tourism }\end{array}$ & 0.671 & 0.742 & 1.266 & 0.617 & 0.027 \\
\hline $\mathbf{H}_{3}$ & Environmental Impact $\rightarrow$ Economic Literacy & -0.574 & -1.088 & 8.291 & 0.069 & 0.230 \\
\hline $\mathbf{H}_{4}$ & $\begin{array}{l}\text { Environmental Impact } \rightarrow \text { Rural competitive } \\
\text { advantage tourism }\end{array}$ & 0.133 & 0.169 & 2.510 & 0.053 & 0.124 \\
\hline $\mathbf{H}_{5}$ & Socio-cultural Impact $\rightarrow$ Economic Literacy & 0.559 & 0.911 & 10.343 & 0.522 & 0.044 \\
\hline $\mathbf{H}_{6}$ & $\begin{array}{l}\text { Socio-cultural Impacts } \rightarrow \text { Rural Competitive } \\
\text { Advantage Tourism }\end{array}$ & 0.645 & 0.657 & 3.747 & 0.612 & 0.028 \\
\hline $\mathbf{H}_{7}$ & $\begin{array}{l}\text { Economic Literacy } \rightarrow \text { Rural Competitive } \\
\text { Advantage Tourism }\end{array}$ & 1.017 & 1.025 & 0.282 & 3.603 & 0.000 \\
\hline $\mathbf{H}_{8}$ & Stakeholder Involvement $\rightarrow$ Economic Literacy & 0.787 & 0.765 & 0.271 & 2.901 & 0.004 \\
\hline $\mathbf{H}_{9}$ & $\begin{array}{l}\text { Stakeholder Involvement } \rightarrow \text { Rural Tourism } \\
\text { Competitive Advantage }\end{array}$ & 0.525 & 0.603 & 0.280 & 0.589 & 0.049 \\
\hline
\end{tabular}


reported a positive and significant relationship between perceived economic benefits and attitudes towards tourism development.

The environmental impact variable had no significant effect on economic literacy, with a p-value of 0.230 . This contradicts the hypothesis that environmental impact has a significant effect on economic literacy. Another influential factor that can increase the competitive advantage of rural tourism is the quality of the environment in preserving natural and cultural values or heritage resources (Angelkova et al., 2011). The perceived environmental impact is the way citizens feel the implications of tourism both positively and negatively on various types of environmental aspects such as pollution, environmental preservation, and others.

The environmental impact variable did not significantly influence rural competitive advantage tourism, with a p-value of 0.124 . This is contrary to the hypothesis that the environmental impact has a significant effect on tourism competitive advantage in rural areas. The environmental impact of tourism is very significant to ensure sustainability. Preservation and maintenance of environmental resources are essential in achieving the competitiveness of objectives (Dwyer \& Kim, 2010). Environmental sustainability is an invaluable and intangible asset in providing competitive advantages for tourist destinations (Grimstad \& Burgess, 2014; Tulsi \& Ji, 2020).

Socio-cultural variables significantly influenced economic literacy, with a p-value of 0.044 . This is consistent with the proposed hypothesis that socio-cultural aspects have a significant effect on economic literacy. Ap and Crompton (1998) explain the positive socio-cultural impacts of increasing and improving living standards, infrastructure or facilities to develop tourism, general protection, enhancing relationships and understanding of various cultures, traditions, heritage, identity, values between visitors and communities local. The socio-cultural impact variable had a significant effect on tourism in rural competitive advantage with a p-value of 0.028 . Local people view tourism as providing various socio-cultural benefits (Choi \& Sirakaya, 2004). Local communities have the opportunity to interact personally with people from diverse backgrounds through tourism activities, broaden their mindsets and increase their pride and enthusiasm through traditional ceremonies.

Economic literacy variables significantly influence rural tourism competitive advantage with a value of $p=0.000$. This is consistent with the hypothesis that Economic Literacy has a significant effect on tourism's competitive advantage in rural areas. The contribution of the local community is very critical to increase the competitive advantage of the rural tourism industry. Two important issues related to society are people's knowledge of the literacy economy and their support for tourism development. Helping local people to understand more about themselves, their life context, and gaining knowledge about tourism strengthens their efforts regarding tourism development and quality of life (Reid et al., 2003), thereby increasing the competitive advantage of rural tourism.

The stakeholder involvement variable had a significant effect on economic literacy with a p-value of 0.004 . This is consistent with the hypothesis that stakeholder involvement has a significant effect on economic literacy. Interestingly, there is a significant and positive relationship between industry players and repositioning in gaining a strong competitive advantage for the development of rural tourism (Lo et al., 2013). The case of Bled, Slovenia, shows that the political dimension is very important to ensure the satisfaction of local people and get their support for the development of tourism, which results in increased public understanding to open businesses near tourist attractions.

The stakeholder engagement variable has a significant effect on the competitive advantage of rural tourism with a p-value of 0.049 . This is consistent with the hypothesis that stakeholder engagement has a significant effect on the competitive advantage of rural tourism. Bueno (1999) also agreed that inter-competition among stakeholders increases competitiveness. Interestingly, there is a significant and positive relationship between industry players and repositioning in gaining a strong competitive advantage for the development of rural tourism.

\subsection{Direct Effect and Indirect Effect between Variables}

Table 4 informs the influence of inter latent variables. From the table, it can be seen that the economic literacy mediates the economic impact on the competitive advantage of rural tourism with a $\mathrm{p}$ value of 0.022 . This is consistent with the hypothesis that the economic literacy mediates the economic impact on the competitive advantage of rural tourism. Several studies have revealed a strong correlation between financial literacy and daily financial management skills (Kotzé \& Smit, 2008; Kim \& Chatterjee, 2013; Sohn, et al., 2012). Research in the United States and other countries has found a relationship between financial literacy and economic impact in the competitive advantage of rural tourism. However, the economic literacy variable proved unsuccessful in mediating between the environmental impact variable on the rural variable tourism competitive advantage with a p-value of 0.959 .

Similarly, Rasoolimanesh et al. (2017) stated that the level of education influences perceptions about tourism; less-educated people evaluate tourism activities positively, while more educated people, negatively. However, these are not in accordance with the findings by Harun et al., (2018) where less-educated people did not realize the benefits of tourism and evaluated it negatively, while those who had 
Table 4: The Influence of Inter Latent Variables

\begin{tabular}{|l|c|c|c|c|c|}
\hline & $\begin{array}{c}\text { Original } \\
\text { Sample (O) }\end{array}$ & $\begin{array}{c}\text { Sample } \\
\text { Mean (M) }\end{array}$ & $\begin{array}{c}\text { Standard } \\
\text { Deviation } \\
\text { (STDEV) }\end{array}$ & $\begin{array}{c}\text { T Statistics } \\
\text { (|O/STDEV|) }\end{array}$ & P Values \\
\hline $\begin{array}{l}\text { Economic Impact } \rightarrow \text { Economic Literacy } \rightarrow \text { Rural } \\
\text { competitive advantage tourism }\end{array}$ & 1.209 & 0.849 & 0.522 & 0.723 & 0.022 \\
\hline $\begin{array}{l}\text { Environmental Impact } \rightarrow \text { Economic Literacy } \rightarrow \\
\text { Rural competitive advantage tourism }\end{array}$ & -0.584 & -1.296 & 11.392 & 0.051 & 0.959 \\
\hline $\begin{array}{l}\text { Socio-cultural Impacts } \rightarrow \text { Economic Literacy } \rightarrow \\
\text { Rural competitive advantage tourism }\end{array}$ & 0.627 & 0.602 & 0.393 & 0.616 & 0.047 \\
\hline $\begin{array}{l}\text { Stakeholder Involvement } \rightarrow \text { Economic Literacy } \rightarrow \\
\text { Rural tourism competitive advantage }\end{array}$ & 0.801 & 0.770 & 0.371 & 2.159 & 0.031 \\
\hline
\end{tabular}

secondary education were positively inclined. Closely related to education is the concept of environmental literacy, part of environmental education, which is analyzed regarding willingness to pay for environmental attributes in the context of small island tourism (Selamat et al., 2016).

The economic literacy variable succeeded in mediating between the socio-cultural impacts on tourism in rural competitive advantage with a p-value of 0.047 . This is consistent with the hypothesis that the economic literacy variable succeeded in mediating between the sociocultural impact variables on tourism in rural competitive advantage. This is supported by those who state that the ability to manage personal finances well are under the umbrella of financial literacy (Isomidinova \& Singh, 2017). The increasing importance of financial literacy is driven primarily by a variety of Socio-cultural Impact factors that currently are a challenge for most European countries (and other industrialized countries). Among other things, this includes structural changes in financial services and the labor market; decline in the welfare state; and the latest demographic changes.

No less importantly, the economic literacy variable also proved successful in mediating between the variables of stakeholder involvement with the tourism of rural competitive advantage with a p-value of 0.031 . This is consistent with the hypothesis that the economic literacy variable mediated between the variables of stakeholder involvement with the tourism of competitive advantage in rural areas. People with poor financial knowledge tend to save less and borrow more. Research in the United States and other countries has found an association between financial literacy and stakeholder involvement in tourism rural competitive advantage; those who are more financially literate are more likely to invest in shares (Danns \& Danns, 2017). Advanced financial knowledge, such as an understanding of risk diversification, seems to be very important in predicting participation in the stock market, however, calculations and the ability to do simple calculations are also relevant. Financial literate individuals tend to be wiser in choosing mutual funds, including those with lower costs (Lusardi \& Mitchell, 2014; Bucher-Koenen et al., 2017).

\section{Conclusions}

Tourism can drive changes in life and revive rural areas through available job opportunities, and improve the quality of life of people. From all independent variables used, only the environmental impact variable did not affect economic literacy and the competitive advantage of rural tourism. The moderating variables indicate that economic literacy mediates the economic impact on rural tourism competitive advantage. Also, socio-cultural impacts on rural competitive advantage tourism, and stakeholder involvement affects rural competitive advantage tourism. However, the economic literacy did not succeed in mediating between environmental impacts on rural competitive advantage tourism. This is because with the increasing understanding of the economy of the community around the tourist attractions, it will increase the business around the tourist attractions that have an impact on environmental damage around the tourist attractions.

\section{References}

Angelkova, T., Koteski, C., Jakovlev, Z. and Mitreva, E. (2011). Sustainability and Competitiveness of Tourism. XI International Conference, Service Sector in Terms of Changing Environment, 27-29 October 2011. Macedonia, 44, 221-227

Ap, J., \& Crompton, J.L. (1998). Developing and Testing a Tourism Impact Scale. Journal of Travel Research, 37(2), 120-130.

Bucher-Koenen, T., Lusardi, A., Alessie, R., \& Van Rooij, M. (2017). How financially literate are women? An overview and new insights. Journal of Consumer Affairs, 51(2), 255-283.

Bueno, P. (1999). Competitiveness in the Tourist Industry and the Role of the Spanish Public Administration. Turizam: Special Issue on Competitiveness in Tourism and hospitality, 47(4), 316-331. 
Chamidah, N., Guntoro, B., \& Sulastri, E. (2020). Marketing Communication and Synergy of Pentahelix Strategy on Satisfaction and Sustainable Tourism. The Journal of Asian Finance, Economics, and Business, 7(3), 177-190.

Choi, H.S.C., \& Sirakaya, E. (2006). Sustainability indicators for managing community tourism. Tourism Management, 27, 1274-1289.

Danns, D. E., \& Danns, G. K. (2017). The Creation of Financial Literacy Programs in Small Developing Countries: An Institutional Model Approach. Journal of International Business Disciplines, 12(2), 16-37. https://faculty.utrgv.edu/ louis.falk/jibd/JIBDnov17.pdf

Dwyer, L., \& Kim, C. (2010). Destination Competitiveness: Determinants and Indicators. Current Issues in Tourism, 6(5), 369-414.

Figgis, P., Bushell, R., \& Eagles, P. F. (2007). Tourism as a tool for community-based conservation and development. In Tourism and Protected Areas: Benefits Beyond Boundaries: the Vth IUCN World Parks Congress (p. 101). CABI.

Getz, D., \& Page, S. J. (2016). Progress and prospects for event tourism research. Tourism Management, 52, 593-631.

Grimstad, S., \& Burgess, J. (2014). Environmental sustainability and competitive advantage in a wine tourism micro-cluster. Management Research Review, 37(6), 553-573.

Harun, R., Chiciudean, G., Sirwan, K., Arion, F., \& Muresan, I. (2018). Attitudes and Perceptions of the Local Community towards Sustainable Tourism Development in Kurdistan Regional Government, Iraq. Sustainability, 10(9), 2991. https:// doi.org/10.3390/su10092991

Ismayanti. (2010). Introduction to Tourism. Jakarta: PT. Gramedia Indonesia

Isomidinova, G., \& Singh, J. S. K. (2017). Determinants of financial literacy: a quantitative study among young students in Tashkent, Uzbekistan. Electronic Journal of Business \& Management, 2(1), 61-75.

Jamal, T., \& Stronza, A. (2009). Collaboration theory and tourism practice in protected areas: Stakeholders, structuring and sustainability. Journal of Sustainable Tourism, 17(2), 169-189.

Jappelli,T. (2010). Economic Literacy: An International Comparison. The Economic Journal, Royal Economic Society, $120(548), 429-451$.

Kim, J., \& Chatterjee, S. (2013). Childhood financial socialization and young adults' financial management. Journal of Financial Counseling and Planning, 24(1), 61.

Kotzé, L., \& Smit, A. (2008). Personal financial literacy and personal debt management: the potential relationship with new venture creation. The Southern African Journal of Entrepreneurship and Small Business Management, 1(1), 35-50.

Lo, M. C., Cheuk, S., \& Atang, A. (2015). Tanjung Datu National Park, Sarawak: Communities' Perceptions towards Its Rural Competitive Advantage. Journal of Sustainable Development, 8(8), 133-146.
Mazilu, M \& Popescu. S. (2010). Regional, Competitive and Qualitative Development of the Romaian Tourism Destination. Geogaphica Timisiensis, 19(1), 135-146.

McKercher, B. (2003). Sustainable tourism development-guiding principles for planning and management. In National Seminar on Sustainable Tourism Development (pp. 5-9).

Mitchell, O. S., \& Lusardi, A. (2015). Financial literacy and economic outcomes: Evidence and policy implications. The Journal of Retirement, 3(1), 107-114.

Muhanna, E. (2007). The contribution of sustainable tourism development in poverty alleviation of local communities in South Africa. Journal of Human Resources in Hospitality \& Tourism, 6(1), 37-67.

Nakatani, M. S. \& Teixeria. R. M. (2009). Resource based view as a perspective for public tourism management research: evidence from two Brazilian tourism destination. Brazilian Administration Review, 6(1), 62-77.

Neto, F. (2003). Anew approach to sustainable tourism development: Moving beyond environmental protection. Natural Resources Forum, 27(3), 212-222

Purnomo, S., Rahayu, E. S., Riani, A. L., Suminah, S., \& Udin, U. (2020). Empowerment Model for Sustainable Tourism Village in an Emerging Country. Journal of Asian Finance, Economics, and Business, 7(2), 261-270. https://doi.org/10.13106/ jafeb.2020.vol7.no2.261

Rasoolimanesh, S. M., Jaafar, M., Marzuki, A., \& Abdullah, S. (2017). Tourist's perceptions of crowding at recreational sites: the case of the Perhentian Islands. Anatolia, 28(1), 41-51.

Reid, D.G., Mair, H., \& George, W. (2003). Community Tourism Planning, A Self-Assessment Instrument. Annals of Tourism Research, 31(3) 623-639.

Scherl, L. M., \& Edwards, S. (2007). Tourism, indigenous and local communities and protected areas in developing nations. Tourism and Protected Areas: Benefits beyond Boundaries, 7188.

Selamat, A. M., Chelamuthu, M. R., \& Suhaili, M. S. (2016). The Impact of Tourism on the Marine Environment of Small Islands: The Case of Pangkor Island, Malaysia. Journal of Modern Education Review, 6(9), 639-647.

Sharpley, R. (2002). Rural tourism and the challenge of tourism diversification: the case of Cyprus. Tourism Management, 23(3), 233-244.

Sohn, S. H., Joo, S. H., Grable, J. E., Lee, S., \& Kim, M. (2012). Adolescents' financial literacy: The role of financial socialization agents, financial experiences, and money attitudes in shaping financial literacy among South Korean youth. Journal of Adolescence, 35(4), 969-980.

Stylidis, D., Biran, A., Sit, J., \& Szivas, E. M. (2014). Residents' support for tourism development: The role of residents' place image and perceived tourism impacts. Tourism Management, $45,260-274$. 
Suranto., Jayanti, A. D., Setyawati, L., \& Jatmika, S. (2020). A Study on the Impact of Cultural Tourism on Indonesian Society. International Journal of Innovation, Creativity and Change, 11(5), $72-86$.

Tosun, C. (2000). Limits to community participation in the tourism development process in developing countries. Tourism Management, 21(6), 613-633.

Truong, D. D., Nguyen, H., \& Duong, T. Q. L. (2020). Factors Influencing Balanced Scorecard Application in Evaluating the Performance of Tourist Firms. Journal of Asian Finance, Economics, and Business, 7(5), 217-224. https://doi. org/10.13106/jafeb.2020.vol7.no5.217

Tulsi, P., \& Ji, Y. (2020). A Conceptual Approach to Green Human Resource Management and Corporate Environmental Responsibility in the Hospitality Industry. Journal of Asian Finance, Economics, and Business, 7(1), 195-203. https://doi. org/10.13106/jafeb.2020.vol7.no1.195

Turco, D.M., \& Kelsey, C. W. (1992). Conducting economic impact studies of recreation and parks special events. Arlington, VA: National Recreation \& Park Association.
Walpole, M.J., \& Goodwin, H.J. (2000). Local Economic Impacts of Dragon Tourism in Indonesia. Annals of Tourism Research, 27(3), 559-576.

Warouw, F. F., Lumeno, S., \& Husung, P. H. (2019). Analysis of Government Responsibility in the Sustainable Tourism Process Study at Manado Bay. International Journal of Innovation, Creativity and Change, 10(7), 170-179.

Wibowo, F. A. A., Riniwati, H., \& Nugroho, I. (2018). The Role of Volunteer for the Management of Conservation-based Ecotourism in Clungup Mangrove Conservation Tambakrejo Village, Sumbermanjing Wetan Sub-District, Malang. Journal of Indonesian Tourism and Development Studies, 6(3), 187193.

Wulandari, D., Narmaditya, B. S., Prayitno, P., \& Ishak, S. (2019). Infrastructure Enhancement and Household Economic Activities: Lesson from Indonesia. Research in World Economy, 10(3), 315-319.

Yoon, Y., Gursoy, D., \& Chen, J.S. (2000). Validating a tourism development theory with structural equation modelling. Tourism Management, 22(4), 363-372. 